University of Nebraska - Lincoln

DigitalCommons@University of Nebraska - Lincoln

2009

\title{
Learning motivation and transfer of human capital development: Implications from psychological capital
}

\author{
Gwendolyn Combs \\ University of Nebraska - Lincoln, gcombs2@unl.edu \\ Fred Luthans \\ University of Nebraska - Lincoln, fluthans1@unl.edu \\ Jakari Griffith \\ University of Nebraska - Lincoln
}

Follow this and additional works at: https://digitalcommons.unl.edu/managementfacpub

Part of the Management Sciences and Quantitative Methods Commons

Combs, Gwendolyn; Luthans, Fred; and Griffith, Jakari, "Learning motivation and transfer of human capital development: Implications from psychological capital" (2009). Management Department Faculty Publications. 54.

https://digitalcommons.unl.edu/managementfacpub/54

This Article is brought to you for free and open access by the Management Department at DigitalCommons@University of Nebraska - Lincoln. It has been accepted for inclusion in Management Department Faculty Publications by an authorized administrator of DigitalCommons@University of Nebraska - Lincoln. 
C H A P TER 4

\title{
Learning motivation and transfer of human capital development:
}

\section{Implications from psychological capital}

\author{
Gwendolyn M. Combs, Fred Luthans, and Jakari Griffith
}

Department of Management, University of Nebraska-Lincoln

As organizations seek to improve competitive advantage and promote high performance work practices, the human capital component of the productivity equation is receiving increasing recognition (Bowen \& Ostroff, 2004; Cavanaugh \& Noe, 1999; Delaney \& Huselid, 1996; Ling \& Jaw, 2006; Ulrich, 1997). Both academics and practitioners now emphasize the "human equation" for competitive advantage (Pfeffer, 1998). Shrinking workforces due to downsizing, outsourcing, and other cost cutting measures have had profound consequences for organizational human capital capacity. Wright, Dunford, and Snell (2001) suggest that organizational profitability and competitive advantage can be sustained only through enhancing product quality and increasing employee productivity. To maximize employee performance, training and development programs are the primary methods that organizations use to build organizational human capital capabilities (Holton, Coco, Lowe, \& Dutsch, 2006). Training magazine (2006) recently estimated that US organizations budgeted US \$56 billion on employee education and learning programs.

Organizations use employee education programs to improve general and specific human capital compatibilities, to direct employee performance, and to influence employee engagement (Holton et al., 2006; Narayan, Steele-Johnson, Delgado \& Cole, 2007). Successful education programs have goals that align with organizational strategy; this alignment is intended to create mutuality between employee work related behaviors and employer short and long term goals (Le Deist \& Winterton, 2005). However, there are mixed opinions regarding the effectiveness of these programs (Kontoghiorghes, 2001). In spite of the large expenditure of financial and other resources, employee educational interventions often fall short of providing the fall benefits for which they were intended (Cromwell \& Kolb, 2004). Consequently, organizations are continually looking for innovative methods not only for delivering education and learning programs but also for ensuring the effectiveness of these programs in creating and enhancing human capital capabilities, and positively impacting job performance (Fumya, Stevens, Oddou, Bird, \& Mendenhall, 2007).

Basically, employee development initiatives focus on the acquisition of knowledge, skills, and abilities (KSAs) necessary to produce peak performance outcomes. Traditionally, targeted KSAs reflect explicit skill sets that are visibly 
connected to task performance. However, research continues to stress that the effectiveness of employee learning and development programs can be greatly impacted by parameters other than the development programs themselves (Combs \& Luthans, 2007).

Important to the effective development of employees are two primary components - learning motivation and the transfer of learning to the work setting (Hawley \& Barnard, 2005; Holton, Chen \& Naquin, 2003; Noe, 1986). Colquitt, LePine and Noe (2000) define learning motivation as "the direction, intensity, and persistence of learning-directed behavior in training [learning] contexts" (p. 678). Through meta-analysis of research on learning motivation they recognized the importance of examining learning motivation and learning transfer by focusing on particular individual characteristics as powerful influencers on learning/education program success. Learning transfer may be defined as the effective application of knowledge, skills, abilities, attitudes, and behaviors that are acquired in learning/educational programs back to the work setting (Cromwell \& Kolb, 2004; Holton \& Baldwin, 2003).

In this chapter, we propose that the recently emerging core construct of psychological capital (Luthans, Avolio, Avey, \& Norman, 2007; Luthans, Youssef, \& Avolio, 2007) may positively influence individual learning motivation (e.g., human capital development) and transfer of learning to the job (e.g., employee performance). Specifically, Fold, Quinones, Sego, and Sorra (1992) suggest that trainee characteristics influence the motivation to perform and the effort that may be expended to perform well. Considerable research has centered on the cognitive processes that impact motivation for learning and the ability to use the learning acquired (Baldwin \& Ford, 1988; Cromwell \& Kolb, 2004; Holton et al., 2003; Machin \& Fogarty, 2003). Goldstein and Ford (2002) suggest that more attention be given to individual psychological processes that can have positive influence on prelearning outcomes (learning motivation) and post-learning performance (learning transfer). Here we use PsyCap to represent the psychological processes. PsyCap, made up of hope, efficacy, optimism, and resiliency, can be used to represent internal factors of individuals that forge positive perceptions of their human capital strengths (e.g., see Cameron, Dutton, \& Quinn, 2003; Luthans, 2002a, 2002b, 2003; Nelson \& Cooper, 2007). These positive psychological strengths allow employees to reduce concentration on what is wrong and what cannot be done and to maximize effectiveness to maintain pursuit of productive performance outcomes.

We will first provide the theoretical background for PsyCap, briefly summarize how PsyCap is being measured and developed, then discuss the theory and research findings regarding learning motivation and transfer of training, and finally we will propose the application of PsyCap to enhance learning motivation and learning transfer.

\section{Theoretical basis for PsyCap and associated constructs}

Psychological capital (PsyCap) is an outgrowth of the positive approach to organizational behavior (Cameron et al., 2003; Luthans, 2002a, 2002b; Luthans \& Youssef, 2007; Luthans, Youssef, \& Avolio, 2007; Nelson \& Cooper, 2007; Rob- 
erts, 2006; Turner, Barling \& Zacharatos, 2002; Wright, 2003), which in turn is rooted in the positive psychology movement that focuses on human psychological strengths and the positive aspects of human functioning (Petersen \& Seligman, 2004; Seligman \& Csikszentmihalyi, 2000; Snyder \& Lopez, 2002). Specifically, positive organizational behavior (POB) involves, "the study and application of positive oriented human resource strengths and psychological capacities that can be measured, developed, and effectively managed for performance improvement in today's workplace" (Luthans, 2002b, p. 59). Following this definition, to be included in $\mathrm{POB}$, a positive psychological resource must be theory and research based, have valid measurement, be "state-like," rather than "trait-like," be open to development through intervention, and finally have performance impact (Luthans, 2002a, 2002b; Luthans, Youssef, \& Avolio, 2007).

The psychological resources that were determined to best meet the POB criteria so far include efficacy, optimism, hope, and resiliency, and when combined, have been termed psychological capital or simple PsyCap (Luthans \& Youssef, 2004; Luthans, Youssef, \& Avolio, 2007). PsyCap is defined as

an individual's positive psychological state of development that is characterized by: (1) having confidence (self-efficacy) to take on and put in the necessary effort to succeed at challenging tasks; (2) making a positive attribution (optimism) about succeeding now and in the future; (3) persevering toward goals and when necessary, redirecting paths to goals (hope) in order to succeed; and (4) when beset by problems and adversity, sustaining and bouncing back and even beyond (resiliency) to attain success.

$$
\text { (Luthans, Youssef, \& Avolio, 2007, p. 3). }
$$

The underlying common agentic capacity running through the four components of PsyCap is the "positive appraisal of circumstances and probability for success based on motivated effort and perseverance" (Luthans, Avolio, et al., 2007, p. 550). There is both conceptual (Luthans, Youssef, \& Avolio, 2007) and empirical (Luthans, Avolio, et al., 2007) support for PsyCap as a second order, core construct. We will next provide a brief overview of each of the four components of PsyCap, the PsyCap measurement instrument, and the PsyCap developmental intervention model.

\section{The hope resource}

Although each of the four PsyCap resources is commonly used in everyday language, in positive psychology, they have a strong theoretical foundation, considerable research and valid measures. For example, Snyder and colleagues have defined hope as a "positive motivational state [italics added] based on an interactively derived sense of successful (a) agency (goal directed energy) and (b) pathways (planning to meet goals)" (Snyder, Irving, \& Anderson, 1991, p. 287). In this regard, hope consists of three major conceptual foundations: agency, pathways, and goals. Specifically, hope is the aggregate of agency (directed determination/ will-power for goal creation), and pathways (planning and strategy identification to achieve goals) (Snyder, Irving, \& Andersen, 1991, p. 287). The will-power 
and pathways thinking operate in a combined iterative process in order to generate hope (Snyder, 2000). The developmental capacity of hope has been clearly supported (Snyder, 2000; Snyder et al., 1991; Snyder, Sympson, Ybasco, Borders, Babyak, \& Higgins, 1996) in clinical applications. For example, there is evidence that hope can be learned through an intentional focus on solution based training interventions (Snyder, 1994), and more recent studies by Snyder $(2000,2002)$ have demonstrated the developmental nature of state hope across multiple studies using a goal based framework. Research supports the idea that hope can also be developed in organizational participants through a carefully designed and focused learning intervention (see Luthans, Avey, Avolio, Norman, \& Combs [2006] and Luthans, Youssef, \& Avolio [2007] for the full background and guidelines for overall PsyCap and each of the four components of hope, efficacy, optimism, and resilience).

\section{The efficacy resource}

Self efficacy, or "one's conviction (or confidence) about his or her abilities to mobilize the motivation, cognitive resources, or courses of action needed to successfully execute a specific task within a given context" (Stajkovic \& Luthans, 1998 b, p. 66) is based on Bandura's $(1986,1997)$ social cognitive theory. Self-efficacy has an extensive body of research including workplace learning and development programs (Combs \& Luthans, 2007; Schwoerer, May, Hollensbe, \& Mend, 2005). Additionally, self-efficacy has demonstrated a strong relationship with performance outcomes (Stajkovic \& Luthans, 1998a).

Bandura's (1997) widely recognized sources of efficacy development include task mastery, vicarious learning or modeling, social persuasion, and psychological or physiological arousal. Task mastery allows individuals to experience success within a specific task domain. When individuals successfully execute a given task, they obtain benefit through awareness of their ability to use cognitive resources to accomplish successful outcomes. This awareness of success, in turn, increases individuals' confidence in their ability to repeat successful performance. Vicarious learning is the second source of efficacy with an emphasis on modeling. For example, an individual's efficacy may be increased by watching relevant others accomplish the targeted task. The third source of efficacy, social persuasion, can be demonstrated when relevant others (e.g., managers or peers) express confidence in the individual's ability to execute a given task or provide positive feedback on progress. These positive affirmations give a confidence boost that encourages successful execution of current and future tasks. Fourth, efficacy is developed through psychological and physiological arousal, or the belief that one is cognitively and physically attending to the task and is mentally engaged in task performance.

\section{The optimism resource}

Although efficacy has been examined more as a domain specific construct, optimism is perceived as a more general positive outcome expectation (Seligman, 
1998). Similar to hope, optimism is commonly discussed in everyday language, but in positive psychology, Seligman (1998) discusses optimism in terms of attributional processes and explanatory styles. He defines optimists as those who make internal, stable, and global attributions regarding positive events, but attribute external, unstable, and specific reasons for negative events. Carver and Scheier (2002) offer complementary work with distinct theoretical underpinnings utilizing an expectancy framework noting, "optimists are people who expect good things to happen to them; pessimists are people who expect bad things to happen to them" (p. 231).

Like hope, optimism has been theorized to have both trait-like and - more applicable to this theoretical foundation for PsyCap - state-like characteristics. For example, Seligman (1998) demonstrates the developmental nature of optimism with his concept of "learned optimism." This argument was suggested many decades ago as Beck (1967) provided theory and research on developing optimistic expectations in clinical patients. In addition, although optimism is often associated with dispositional optimism, Carver and Scheier (2002) have recently discussed plausible change in an optimistic direction and propose the need of intervention strategies to portray the developmental nature of optimism.

Overall, optimism development has been used in clinical interventions and practitioner-oriented leadership books, and theorized and researched by widely recognized positive psychologists such as Seligman (1998). From a POB perspective, we propose that the realistic optimism of organizational participants can be instrumental in increasing human capital capacity, and that the developmental nature of optimism can be a mechanism to improve the effectiveness of employee learning interventions.

\section{The resilience resource}

Resilience, the fourth resource of psychological capital, is identified in positive psychology as one's ability, when faced with adversity, to rebound or "bounce back" from a setback or failure (Masten, 2001; Masten \& Reed, 2002). It has been traditionally focused on "at risk" youth who succeed despite severe odds and adversity. Luthans (2002a, p. 702) defines PsyCap resilience as "the capacity to rebound or bounce back from adversity, conflict, failure, or even positive events, progress, and increased responsibility." Resilience focuses on attention to risks, assets, and process strategies for coping with and adapting to life events (Luthans, Vogelgesang, \& Lester, 2006; Masten \& Reed, 2002). Persons who are high in resiliency demonstrate high flexibility and openness to experiences that are novel, different, and ambiguous (Tugade \& Fredrickson, 2004). When negative events occur, the resilient individual will assess assets in the environment and identify resources that can mitigate the impact and effect of the negative occurrence. They will draw from internal (cognitive) and external (networks) resources that will assist and permit recalibration and balance restoration (Coutu, 2002; Masten \& Reed, 2002).

Positive emotions have also been shown empirically to enhance resilience in the face of negative events (Tugade, Fredrickson, \& Barrett, 2004). As this dy- 
namic learning process of resilience focuses on positive adaptation, developmental interventions serving to maximize assets or resources and minimize risk factors (Masten, 2001; Masten \& Reed, 2002) provide successful strategies for resilience focused interventions (Bonanno, 2005; Luthans, Vogelgesang, \& Lester, 2006).

\section{Support for the psychological capital core construct}

A developing body of research suggests PsyCap is a higher order construct. PsyCap includes hope, optimism, resilience and efficacy (Luthans, Youssef, \& Avolio, 2007). It predicts performance outcomes in the context of work better than any one of its underlying constructs independently (Luthans, Avolio, et al., 2007). Theory and research support the importance of second order constructs for understanding various organizational outcomes and processes. For example, the recent introduction of authentic leadership theory consists of self-awareness, balanced processing, transparency, and a moral ethical component (Walumbwa, Avolio, Gardner, Wernsing, \& Peterson, in press). Judge and Bono's (2001) theoretical discussion on core self-evaluations adopts a similar position, with core self-esteem, generalized efficacy, locus of control, and emotional stability as its underlying components. Indeed, the identification and utilization of second order factors has become increasingly common in organizational behavior research (Law, Wong, \& Mobley, 1998).

Research has empirically demonstrated the conceptual independence and discriminant validity of the constructs that make up PsyCap (Bryant \& Cvengros, 2004; Carifio \& Rhodes, 2002; Luthans, Avolio, et al., 2007; Magaletta \& Oliver, 1999; Youssef \& Luthans, 2007) in the positive psychology and positive organizational behavior literature. Additional support for PsyCap as a second order core construct is demonstrated in psychological resource theory (see Hobfoll, 2002) and Fredrickson's (2001) broaden-and-build theory of positive emotions. For example, Fredrickson's broaden-and-build theory stresses that positive emotions, along with the broadened thinking they stimulate, interact with one another to build enduring personal and social resources. In effect, positive emotions allow individuals to cope more effectively with adversity through their influence on cognitive functioning and well-being (Fredrickson, 2003; Fredrickson \& Joiner, 2002). Using a similar rationale as Fredrickson (2001), PsyCap is proposed to act in a integrated, interactive, and broadening way (Luthans \& Youssef, 2007; Luthans, Youssef, \& Avolio, 2007).

PsyCap reflects an underlying core agentic capacity that relates to adaptation and change, due to its positive influence on how individuals construct their experiences and consider alternatives when faced with a problem. For example, individuals with high hope may be better equipped to identify pathways to important goals, yet their added experience of confidence allows them to secure and identify resources necessary for goal pursuit because they can put forth the effort to overcome potential obstacles. Moreover, those high in optimism may have positive expectations, which in turn influence assessments of potential resources needed to successfully accomplish a goal. Taken together, the combined effects may prove beneficial to the development of human capital. 


\section{PsyCap Questionnaire and micro intervention}

PsyCap is measured by the PsyCap Questionnaire (PCQ), which is comprised of 24 items (for the complete instrument see Luthans, Youssef, \& Avolio, 2007, pp. 237-238). The PCQ contains six items for each of the subscales of hope, optimism, efficacy, and resilience with a Likert-type response scale ranging from $1=$ strongly disagree to $6=$ strongly agree. Specific items were drawn from recognized measures of hope (Snyder et al., 1996), optimism (Scheier \& Carver, 1985), efficacy (Parker, 1998), and resilience (Wagnild \& Young, 1993). Sample items are: efficacy - "I feel confident analyzing a long term problem to find a solution"; optimism - "when things are uncertain for me at work, I usually expect the best"; resiliency - "I can usually manage difficulties one way or another at work"; and hope - "At the present time I am energetically pursuing my work goals."

The PsyCap Intervention (PCI) is a one to three hour learning intervention that incorporates the development research and implementation guidelines surrounding the four component constructs (hope, optimism, efficacy/confidence, and resilience) and overall PsyCap. This PCI incorporates modules that cover development practices and procedures for each of the four state-like resources. We provide a summary of the organization of the modules for each component of the PCI (for more detailed review see, Luthans, Avey, et al., 2006 and Luthans, Youssef, \& Avolio, 2007).

The hope resource may be developed through a series of individual and group based activities that focus on specifying goals and their component parts, developing pathways or strategies for accomplishing goals, and identifying obstacles that may impede goal accomplishment (Snyder, 2000). For example, participants are asked to list and prioritize several goals that are important to them. These goals are discussed and re-written to ensure that the goals are measurable, with clear beginning and ending points, are broken down into subgoals, and are expressed in concrete terms concentrating on the positive desired outcome (e.g. "“what I want to accomplish") versus the negative aspect of the goal (e.g. "what I want to avoid"). Once goals are properly written they are examined for identification of obstacles and discussion of ways to avoid and work around or through obstacles. These exercises provide clarity and direction that aid agentic and pathways thinking.

Realistic optimism is developed through exercises to promote the expectation of positive outcomes and building of efficacy/confidence. The examination of obstacles in hope training is followed by encouragement of positive attributions (i.e., internal attributions for "good" events and external attributions for "bad" events) that can lead to more positive beliefs in ability to satisfactorily accomplish goals. Additionally, feelings of accomplishment obtained through group activities and feedback can in turn lead to more optimistic perceptions for present and future efforts.

Based on Bandura (1997), efficacy development processes included enactive mastery, modeling, social persuasion, and psychological and physiological arousal. The previously described goal exercise incorporated mastery and modeling experiences through successful mapping of goals and strategies and the ability to observe the success of others in group discussions, dyad exchanges, and facilitator examples. Additionally, positive affirmations regarding participant ap- 
proaches and feedback are obtained from the facilitator and other group members. Similarly, identification of different pathways for goal accomplishment induces visualization of positive goal pursuit.

The PCI development of resilience targets assets, risk factors, and influence processes. In the intervention participants are asked to identify and describe an adverse occurrence. Participants are then led through a series of questions such as: "What is at risk?," "How can I minimize the risk?," "What control do I have?," and "What are my options?" These questions and associated exercises are designed to stimulate participants' cognitive capacities surrounding framing of the adversity, risk management, appropriate tools for responding to risks, the identification of personal resources (e.g., skills and personal networks), and taking responsibility and ownership for success.

\section{Learning interventions, human capital, and performance}

There is continuing debate in the literature about the effectiveness of learning and development programs and their effects on performance outcomes. However, Chen and Klimoski's (2007) recent review of the training literature observed an overall positive relationship between training (learning) and development on organizational performance outcomes. They concluded that training and development are likely to lead to employee productivity gains (e.g., Tharenou, Saks, \& Moore, 2007), that skill acquisition and transfer of training are predictive of individual job performance (e.g., Alliger, Tannenbaum, Bennett, Traver, \& Shortland, 1997), and that training can impact performance beyond the micro level (e.g., teams and firm performance) (Alliger et al., 1997). In sum, an emphasis on learning and development by both academics and practitioners is common because of its direct connections to the development of human capital (Zula \& Chermack, 2007) and its relationship to organizational performance outcomes (Salas \& Cannon-Bowers, 2001; Salas \& Kosarzycki, 2003). Fundamental to these findings is the concept that employee learning programs, when administered effectively, increase employee productivity and performance outcomes.

Although the above offers empirical support for the positive effects of employee learning and development interventions on performance, there are also examples in the literature where such programs may not produce the intended results (e.g., Colquitt et al., 2000; Saks, 1995) and where the design of development programs itself cannot explain the variance found in transfer outcomes (Baldwin \& Ford, 1988). Training and development theorists argue that the variance underlying learning and development programs is closely related to such factors as learning motivation, learning program design, and learning transfer climate (Holton, Bates, \& Ruona, 2000; Holton et al., 2003; Kontoghiorghes, 2004). For example, studies have revealed learning and development programs are most effective when individuals are motivated to engage in the learning activity and apply that learning to an appropriate work situation (Bates, Holton, Seyler, \& Carvalho, 2000; Cromwell \& Kolb, 2004; Facteau, Dobbins, Russell, Ladd, \& Kudisch, 1995; Machin \& Fogarty, 2004). 
In other studies, differences in efficacy have been related to employees actively engaging in developmental activities that in turn affect performance impact. Using trainee characteristics to describe underlying components of learning motivation, and transfer, Burke and Hutchins (2007, p. 278) argue there is a "paucity of empirical data to support widely touted active learning methods ... and transfer research may need to transform and potentially meld with the performance improvement literature." Given these observations, we argue that employee learning and development research would greatly benefit from integrating intervention capacities with performance-oriented constructs that may improve the outcomes of human capital development and, subsequently, organizational performance.

A key to the success of this integration would be to understand the context for learning motivation and transfer back to the job. Research on learning motivation has focused strongly on cognitive and motivational characteristics that stimulate and enhance greater levels of employee engagement in learning and development efforts. However, the nature of the specific cognitive and motivation strategies needed to trigger positive employee engagement in learning has only recently been addressed. In their review of the transfer and training literature, Burke and Hutchins (2007) identified cognitive ability, self-efficacy, motivation, personality, perceived utility, perception of job variables, and locus of control as being central variables in the study of trainee characteristics and their effect on learning motivation.

More prevalent discussions of the motivational frameworks have centered on how individual variables and cognitive capacities may operate in concert with organizational environmental factors (Burke \& Hutchins, 2007; Holton, Bates, \& Ruona, 2000). For example, Colquitt et al. (2000) established that training motivation is the composite of many interacting individual and situational variables. Just focusing on the individual variables, the researchers found that a person's cognitive abilities, self-efficacy, anxiety, and conscientiousness formed the psychological base of training motivation. Furthermore, Colquitt et al. (2000) found that self-efficacy and valence (as individual difference variables) related to motivation to learn and all training outcomes examined. From this research they suggest that "trainers would do well to leverage both of these constructs at the beginning of training ... by demonstrating the behaviors that are the target of training or by persuading trainees they are capable of succeeding (p. 699)."

Several studies have highlighted the important role of situational characteristics, indicating the degree to which they enhance the conditions that lead to performance improvement. The basic premise is that situations embody contextual features such as training climate and perceptions of supervision that reciprocally influence effort expenditures. For example, Quinones (1995) found that the way in which training was framed had a positive affect on learner attitudes, leading to positive training outcomes. Other researchers have noted climate influences learning and development the most when there is a clear understanding about the purpose and significance of the training intervention. Employees who see their training environment as relatively uniform and clear may feel more comfortable applying acquired learning when compared to individuals who view the context as not conducive to learning transfer (De Kok \& Uhlaner, 2001). Given that work contexts are 
ever changing and growing increasingly complex, attention to context in ensuring the transfer of KSAs acquired through employee learning and development programs is critically important for building and sustaining human capital capacity in organizations (Valeda, Caetano, Michel, Lyons, \& Kavanagh, 2007).

\section{Transfer of training, learning motivation, and the interface with PsyCap}

We propose that PsyCap can enhance the outcomes of employee education programs at two very important intersections: transfer of training and learning motivation. Specifically, we argue that persons with higher levels of PsyCap may be more inclined to demonstrate greater engagement and motivation in the learning intervention and greater transfer of learning to the work setting. PsyCap has been demonstrated empirically to be malleable and open to change (Luthans, Avey, et al., 2007; Luthans, Avolio, et al., 2007). Therefore, we propose that PsyCap may make an important contribution to establishing and managing the effectiveness of employee development programs. Further, the demonstrated association between PsyCap and enhanced performance (e.g., Luthans, Avolio, et al., 2007) suggests that in organizations where employee learning/educational initiatives (i.e., building human capital capacity) are linked to organizational strategic focus, PsyCap may make an important contribution to enhanced development of human capital capacity.

\section{The implications of PsyCap on the transfer of training}

As organizations continue to expend large amounts of financial and other resources on employee learning, it is important to determine how learning transfer can be ensured and/or improved. Both individual (e.g., Machin \& Fogarty, 2004) and contextual (e.g., Cromwell \& Kolb, 2004) variables have been included in taxonomies that can impact transfer. Research has consistently given attention to the constructs that influence post-intervention transfer behaviors (e.g., Baldwin \& Ford, 1988; Holton et al., 2000; Orpen, 1999; Tracey, Hinkin, Tannenbaum, \& Mathieu, 2001). Additionally, both direct effect and mediated models have been supported (Machin \& Fogarty, 2004). Such transfer research would seem to benefit from a change in approach from just listing variables or topologies of individual factors affecting learning motivation and transfer (Holton et al., 2003). Specifically, to move inquiry farther, more attention needs to be given to constructs that can be manipulated and managed to improve the effectiveness of learning and development interventions (Hawley \& Barnard, 2005). The theory and examination of PsyCap will allow the examination of theory driven constructs that can be developed in learning participants, can develop human capital, and can enhance the effectiveness of organizational learning/educational programs.

Much of the research surrounding learning transfer focuses on either direct behaviors or behavioral intentions to act subsequent to the learning intervention. For example, Gollwitzer (1993) proposed that there are two kinds of intentions 
that impact goal achievement: goal intentions and implementation intentions. Goal intentions refer to desired end-state and requisite motivation and commitment to accomplish desired outcomes. Implementation intentions refer to the identification and recognition of situational cues or environmental conditions that activate goal directed actions. Similarly, PsyCap and the individual and interactive properties of its component constructs may impact intentions following educational interventions. In particular, PsyCap through all of its components (hope, optimism, efficacy/confidence, and resilience) may facilitate transfer in several ways. For example, following the task specific training, organizations might engage the PsyCap Intervention (CPI) introduced earlier (also see Luthans, Avey, et al., 2006; Luthans, Youssef, \& Avolio, 2007) to guide the process for identification of specific transfer goals related to the performance task.

In most learning programs, lots of information and several process alternatives are typically presented. Individuals need to assess the various aspects of such learning programs in terms of applicability to their specific work setting. The hope dimensions of agency and pathways as drawn from the PsyCap Intervention would require individuals to reflect on the learning program and to specify goals to use the newly acquired knowledge back on the job. The PsyCap Intervention requires these goals to be concrete and measurable and to have an approach rather than avoidance framework. Next, subgoals would be developed to identify incremental and related processes that could facilitate successful goal accomplishment. Following the determination of goals and subgoals, again drawing from the hope aspect of the PsyCap Intervention, individuals would establish pathways (proactive strategies and contingency plans) for accomplishing each goal and subgoal. Finally, obstacles that the trainee might face in executing the transfer goals would be examined, and ways of overcoming or resolving obstacles identified. Further, this PsyCap Intervention process supports the development of realistic optimism and establishes positive expectations and attributional styles for success in transferring acquired learning to the work setting.

The efficacy component of the PsyCap Intervention can be used to build the trainee's confidence in the task domain of the educational program (Bandura, 2000; Combs \& Luthans, 2007). Helping participants to establish and succeed at incremental goals surrounding the learning experience can lead to strong feelings of accomplishment and internal positive attributions. Opportunities to enact the learning as it relates to the work environment builds confidence in the trainee's ability to apply or transfer learning to the work situation. The efficacy component of the PsyCap Intervention - involving the observation of others modeling appropriate and effective implementation behaviors and attitudes regarding the learning content of the program - allows participants to conclude that they too can be successful in applying acquired KSAs. Instructor-led and group-based feedback to learning participants can serve as the social persuasion dimension of the efficacy component of the PsyCap Intervention and, of course, provides positive affirmation for successful transfer performance. In total, through the PsyCap Intervention, trainees' cognitive resources can be activated, positive psychological states can be energized, and negative physiological states can be minimized or replaced, so that their acquired KSAs can be effectively transferred to the work setting. 
Even when the learning and development programs are on target with organizational needs, resistance to transfer to the work setting can emanate from organizational contextual factors such as lack of supervisory and peer support, work system factors, feedback systems, openness to change, lack of resources, and lack of opportunity to use acquired KSAs (Burke \& Hutchins, 2007; Facteau et al., 1995; Ford \& Weissbein, 1997; Hawley \& Barnard, 2005; Holton et al., 2000, 2003). For example, Cromwell and Kolb (2004) conducted a study of participants in a large scale development program consisting of 56 hours of instruction over a 12 week period. Their examination of work environmental factors on transfer showed that lack of management support and lack of time to apply learning presented significant barriers to learning transfer. Similarly, Hawley and Barnard (2005), in a study of training professionals using mixed methods analysis (surveys and interviews), found that learning transfer was negatively influenced when supervisory support was missing. Given the demonstrated negative influence of these transfer climate issues, we would propose that a PsyCap Intervention may be able to overcome such problems. These situations of unfavorable context for transfer may be best resolved through enhanced resilience and hope.

The PsyCap Intervention focuses on building the individual's ability to anticipate adversity in goal accomplishment and to envision ways to overcome obstacles or "goal blockers" that can lead to disengagement from goal pursuit. The resilience component specifically focuses on risk factors that may contribute to undesirable events and assets that may mitigate or absolve undesirable events (Masten \& Reed, 2002). The intervention would target the resources that would best enable trainees to work around negative contextual factors (e.g., lack of supervisory and peer support) and seek ways to use acquired skills on the job. One method may be to educate others on the benefits the trainee can now provide through his or her use of the newly acquired KSAs. Another method may be to obtain support through a community of learners or alums who went through the same learning experience.

\section{The implications of PsyCap for learning motivation}

Besides the positive impact that PsyCap may have on the transfer of training, we also propose its impact on the other major challenge of today's education programs, the motivation to learn. Learning motivation or the individual's readiness and desire to learn and acquire knowledge from the training is recognized as a critical factor for the effectiveness of any human capital development effort (Noe, 1986; Wiethoff, 2004). Wiethoff (2004) calls for more theoretical discussion of the motivational process when examining learning programs. More specifically, attention is needed on the development of appropriate employee attitudes towards learning and how these attitudes may contribute to learning motivation (Tracey, Hinkin, Tannenbaum, \& Mathieu, 2001). In terms of individual differences, research on learning motivation has tended to focus on variables that are considered more stable and trait-like, such as need for achievement, personality characteristics, cognitive abilities, self-efficacy, and valence 
(Colquitt et al., 2000). Additionally, Baldwin, Magjuka, and Loher (1991) found that learning motivation had positive relationships to both the level of learning acquired in the learning intervention itself, as well as the demonstration of transfer of learning to the job setting.

We propose that PsyCap can contribute to learning motivation in two important ways. First, the use of the PsyCap Questionnaire (PCQ) as a participant's needs assessment, and second, use of the PsyCap Intervention to help frame their participation in the learning program. Prior to, and in preparation for learning programs, the PCQ can be administered to assess participant's level of PsyCap. This assessment would gauge the participant's hope, optimism, efficacy/confidence, and resilience. Such an assessment would help objectively identify individuals who may need assurances of the importance of the learning program for personal, unit level, and organizational performance. More specifically, this use of the PCQ can provide insights and identification of particular psychological and cognitive individual differences that can diagnose and promote more effective results from employee learning programs.

The use of the PCQ measure prior to the educational program can provide insights as to those who may need to participate in a PsyCap Intervention in order to build their hope, optimism, confidence, and resiliency as these relate to the educational program. Following the PCQ assessment, it can be determined whether the full PsyCap Intervention or an abbreviated version may be presented to encourage participants to set preintervention goals that focus on what they need and want to gain from the learning opportunity. Identification of personal resistance to the learning experience (i.e., uncoupling dependence on status quo systems or processes, lack of vision regarding the usefulness of new information) can be addressed. Guided imagery sessions may allow participants to visualize how the new learning might be beneficial to task performance, and in turn facilitate the transfer back to the job.

The literature on message and communication framing has relevance to this discussion in its application to the promotion of the learning program and the enhancement of learning motivation. Framing refers to influencing individual decision-making regarding an object, message, or task based on verbal or physical presentation of "packaging." Research on framing merges the research on information processing, individual differences, attributions, and decision outcomes (Kuvaas \& Selart, 2004; Levin, Schneider, \& Gaeth, 1998; McIntosh, 2005). Ruth and York (2004), in a laboratory experiment of college students, examined the effect of information characteristics (message source, information type, and reference point) on attitudes towards an organization by looking at how information is presented and framed. They found that information source and referent point had significant effects on attitudes about the organization (e.g., reputation). More related to learning interventions, Holladay, Knight, Paige, and Quinones (2003) examined framing of diversity training programs. They found that different frames for diversity training had significant influence on pretraining attitudes towards diversity training. Thus, framing is itself a human capital capacity concerned with influence and persuasion that can impact learning motivation and attitude towards learning. 
PsyCap can facilitate learning motivation by focusing attention on how learning interventions are described and promoted so as to facilitate appropriate framing to enhance learning motivation. For example some approaches to framing might include: providing testimonials from previous participants about the benefits of the learning intervention and/or providing examples of how the targeted KSAs of the learning intervention can be or have been used to enhance individual and organizational effectiveness. Additionally, managers of those who will be attending the learning intervention can confirm and reinforce the importance of the learning experience by pointing out and discussing with the employee how the targeted KSAs will positively impact individual and unit performance. These types of activities can allow the trainees to enter the learning environment with confidence, directed towards goal creating and accomplishment, with a positive outcome expectation, and the inclination to redirect resources and energies to overcome adversity.

\section{Conclusion}

In this chapter we have attempted to expand the application and utility of the newly emerging core construct of psychological capital to an area critically important to high performance organizations. More specifically, the enormous organizational resources devoted to building and sustaining human capital through employer-sponsored or delivered learning and education programs demands continued analysis and investigation of how to ensure the effectiveness of such programs. Learning motivation (antecedent) and transfer of learning (outcome) are two particularly challenging elements in the learning/education program development formula that if addressed correctly can minimize failure and maximize success.

In developing and sustaining human capital, the synergy of PsyCap through its independent yet interacting components of hope, optimism, efficacy/ confidence, and resilience - seems to offer great promise for influencing learning effectiveness. In this instance the unique duality of PsyCap is its potential capacity both to influence the acquisition of KSAs for task performance (i.e., positively impact the motivation to learn), and to serve as a strategic intervention to increase the desired outcome of learning transfer. Even in environments where transfer may be difficult, organizations can receive return on the learning investment because the employees will be cognitively positioned to stretch, adapt, and reformulate their experiences in the learning environment and beyond in the work setting. Moreover, the engagement of PsyCap to facilitate constructive positive thoughts, attitudes, and behaviors allows employees to energize, direct, and to take ownership for their success from the learning and development effort, creating an upward spiral effect, a contagion effect. Additionally, we envision PsyCap as a tool for learning facilitators to enhance the highly desirable positive psychological states of their participants' confidence, hope, resilience, and optimism. The measurement of the PsyCap of the participants can be used to support the needs assessment and preparation for learning. Overall, PsyCap would seem to have important implications for jump-starting new thinking and ways to help solve 
two major challenges currently facing human capital development: increased motivation to learn and transfer of training back to the job for more effective performance and competitive advantage.

\section{References}

Alliger, G. M., Tannenbaum, S. I., Bennett, W. Jr., Traver, H., \& Shortland, A. (1997). A meta-analysis of the relations among training criteria. Personnel Psychology, 50, 341-358.

Baldwin, T. T., \& Ford, K. J. (1988). Transfer of training: A review and directions for future research. Personnel Psychology, 41(1), 63.

Baldwin, T. T., Magjuka, R. J., \& Loher, B. T. (1991). The perils of participation: Effects of choice of training on training motivation and learning. Personnel Psychology, 44, 51-65.

Bandura, A. (1986). Social foundations of thought and action: A social cognitive theory. Englewood Cliffs, NJ: Prentice-Hall.

Bandura, A. (1997). Self-efficacy: The exercise of control. New York: W. H. Freeman.

Bandura, A. (2000). Cultivate self-efficacy for personal and organizational effectiveness. In E. Locke, ed., Handbook of principles of organizational behavior (pp. 120-136). Oxford, UK: Blackwell.

Bates, R. A., Holton. E. F., Seyler, D. L., \& Carvalho, M. A. (2000). The role of interpersonal factors in the application of computer-based training in an industrial setting. Human Resource Development International, 3(1), 19-42.

Beck, A. T. (1967). Depression: Clinical, experimental and theoretical aspects. New York: Harper and Row.

Bonanno, G. A. (2005). Clarifying and extending the construct of adult resilience. American Psychologist, 60, 265-267.

Bowen, D. E., \& Ostroff, C. (2004). Understanding HRM-firm performance linkages: The role of the "strength" of the HRM system. Academy of Management Review, 29(2), 203-221.

Bryant, F. B., \& Cvengros, J. A. (2004). Distinguishing hope and optimism. Journal of Social and Clinical Psychology, 23, 273-302.

Burke, L. A., \& Hutchins, H. M. (2007). Training transfer: An integrative literature review. Human Resources Development Review, 6(3), 263-296.

Cameron, K., Dutton, J., \& Quinn, R. (2003). Positive organizational scholarship. San Francisco: Berrett-Koehler.

Carifio, J., \& Rhodes, L. (2002). Construct validities and the empirical relationships between optimism, hope, self-efficacy, and locus of control. Work, 19, 125-136.

Carver, C., \& Scheier, M. (2002). Optimism, in C. R. Snyder \& S. Lopez, eds., Handbook of positive psychology (pp. 231-243). Oxford, UK: Oxford University Press.

Cavanaugh, M. A., \& Noe, R. A. (1999). Antecedents and consequences of relational components of the new psychological contract. Journal of Organizational Behavior, 20(3), 323-340.

Chen, G., \& Klimoski, R. J. (2007). Training and development of human resources at work: Is the state of our science strong? Human Resource Management Review, 17(2), 180-190.

Colquitt, J. A., LePine, J. A., \& Noe, R. A. (2000). Toward an integrative theory of training motivation: A meta-analytic path analysis of 20 years of research. Journal of Applied Psychology, 85(5), 678-707. 
Combs, G. M., \& Luthans, F. (2007). Diversity training: An analysis of the impact of self-efficacy. Human Resource Development Quarterly, 18(1), 91-120.

Coutu, D. L. (2002). How resilience works. Harvard Business Review, 80(3), 46-55.

Cromwell, S. E., \& Kolb, J. A. (2004). An examination of work environment support factors affecting transfer of supervisory skills training to the workplace. Human Resource Development Quarterly, 75(4), 449-471.

De Kok, J., \& Uhlaner, L. M. (2001). Organization context and human resource management in the small firm. Small Business Economics, 77, 273-291.

Delaney, J., \& Huselid, M. (1996). The impact of human resource management practices on perceptions of organizational performance. Academy of Management Journal, 39(4), 949-969.

Facteau, J. D., Dobbins, G. H., Russell, J .E. A., Ladd, R. T., \& Kudisch, J. D. (1995). The influence of general perceptions of the training environment on pretraining motivation and perceived training transfer. Journal of Management, 27(1), 1-25.

Ford, J. K., \& Weissbein, D. A. (1997). Transfer of training: An updated review and analysis. Performance Improvement Quarterly, 70(2), 22-41.

Ford, K. J., Quinones, M. A., Sego, D. J., \& Sorra, J. S. (1992). Factors affecting the opportunity to perform trained tasks on the job. Personnel Psychology, 45(3), 511.

Fredrickson, B. L. (2001). The role of positive emotions in positive psychology: The broaden-and-build theory of positive emotions. American Psychologist, 56, 218-226.

Fredrickson, B. L. (2003). The value of positive emotions. American Scientist, 91,330-335.

Fredrickson, B. L., \& Joiner, T. (2002). Positive emotions trigger upward spirals toward emotional well being. Psychological Science, 13, 172-175.

Furuya, N., Stevens, M. J., Oddou, G., Bird, A., \& Mendenhall, M. E. (2007). The effects of HR policies and repatriate self-adjustment on global competency transfer. Asia Pacific Journal of Human Resources, 45(1), 6.

Goldstein, I., \& Ford, J. K. (2002). Training in work organizations (4th ed.). Boston: Wadsworth.

Gollwitzer, P. M. (1993). Goal achievement: The role of intentions. In W. Stroebe \& M. Hewstone, eds., European Review of Social Psychology (pp. 141-185). Chichester, UK: Wiley.

Hawley, J. D., \& Barnard, J. K. (2005). Work environment characteristics and implications for training transfer: A case study of the nuclear power industry. Human Resource Development International, 8(1), 65-80.

Hobfoll, S. (2002). Social and psychological resources and adaptation. Review of General Psychology, 6, 307-324.

Holladay, C. L., Knight, J. L., Paige, D. L., \& Quinones, M. A. (2003). The influence of framing on attitudes toward diversity training. Human Resource Development Quarterly, 14(3), 245-263.

Holton, E. F., \& Baldwin, T. T. (2003). Making transfer happen: An action perspective on learning transfer system. In E. F. Holton \& T. T. Baldwin, eds., Improving learning transfer in organizations (pp. 3-15). San Francisco: Jossey-Bass.

Holton, E. F., Bates, R. A., \& Ruona, W. E. A. (2000). Development of a generalized learning transfer system inventory. Human Resource Development Quarterly, 77(4), 333-360.

Holton, E. F., Chen, H., \& Naquin, S. S. (2003). An examination of learning transfer system characteristics across organizational settings. Human Resource Development Quarterly, 14(4), 459-482.

Holton, E. F., Coco, M. L., Lowe, J. L., \& Dutsch, J. V. (2006). Blended delivery strategies for competency-based training. Advances in Developing Human Resources, 8(2), 210-228.

Judge, T. A., \& Bono, J. E. (2001). Relationship of core self-evaluation traits - self-esteem, generalized self-efficacy, locus of control, and emotional stability - with job-satisfac- 
tion and performance: A meta-analysis. Journal of Applied Psychology, 86, 80-92. Psychological capital 89

Kontoghiorghes, C. (2001). Factors affecting training effectiveness in the content of the introduction of new technology: A U.S. case study. International Journal of Training and Development, 5(4), 248-260.

Kontoghiorghes, C. (2004). Reconceptualizing the learning transfer conceptual framework: empirical validation of a new systemic model. International Journal of Training \& Development, 8(3), 210-221.

Kuvaas, B., \& Selart, M. (2004). Effects of variable framing on cognitive processing and evaluation. Organizational Behavior and Human Decision Processes, 95, 198-207.

Law, K. S., Wong, C., \& Mobley, W. H. (1998). Toward a taxonomy of multidimensional constructs. Academy of Management Review, 23, 741-755.

Le Deist, F. D., \& Winterton, J. (2005) What is competence? Human Resource Development International, 8, 27-46.

Levin, I. P., Schneider, S. L., \& Gaeth, G. J. (1998). All frames are not created equal: Typology and critical analysis of framing effects. Organizational Behavior and Human Decision Processes, 76(2), 149-188.

Ling, Y., \& Jaw, B. (2006). The influence of international human capital on global initiatives and financial performance. International Journal of Human Resource Management, 17(3), 379-398.

Luthans, F. (2002a). The need for and meaning of positive organizational behavior. Journal of Organizational Behavior, 23, 695-706.

Luthans, F. (2002b). Positive organizational behavior: Developing and managing psychological strengths. Academy of Management Executive, 16, 57-72.

Luthans, F. (2003). Positive organizational behavior (POB): Implications for leaders and HR development and motivation. In R. M. Steers, L. W. Porter, \& G. A. Begley, eds., Motivation and leadership at work (pp. 187-195). New York: McGraw-Hill/Irwin.

Luthans, F., Avey, J. B., Avolio, B. J., Norman, S., \& Combs, G. M. (2006). Psychological capital development: Towards a micro-intervention. Journal of Organizational Behavior, 27, 387-393.

Luthans, F., Avolio, B. J., Avey, J. B., \& Norman, S. M. (2007). Positive psychological capital: Measurement and relationship with performance and satisfaction. Personnel Psychology, 60, 541-572.

Luthans, F., Vogelgesang, G. F., \& Lester, P. B. (2006). Developing the psychological capacity of resiliency. Human Resource Development Review, 5(1), 25-44.

Luthans, F., \& Youssef, C. M. (2004). Human, social, and now positive psychological capital management: Investing in people for competitive advantage. Organizational Dynamics, 33, 143-160.

Luthans, F., \& Youssef, C. M. (2007). Emerging positive organizational behavior. Journal of Management, 33, 321-349.

Luthans, F., Youssef, C. M., \& Avolio, B. J. (2007). Psychological capital. New York: Oxford University Press.

Machin, M. A., \& Fogarty, G. (2003). Perceptions of training related factors and personal variables as predictors of transfer implementation intentions. Journal of Business and Psychology, 18, 51-71.

Machin, M. A., \& Fogarty, G. J. (2004). Assessing the antecedents of transfer intentions in a training context. International Journal of Training and Development, 8(3), 222-236.

Magaletta, P. R., \& Oliver, J. M. (1999). The hope construct, will and ways: Their relations with self-efficacy, optimism, and well being. Journal of Clinical Psychology, 55, 539-551.

Masten, A. S. (2001). Ordinary magic: Resilience process in development. American Psychologist, 56, 227-239. 
Masten, A. S., \& Reed, M. G. J. (2002). Resilience in development. In R. C. Snyder \& S. J. Lopez, eds., Handbook of positive psychology (pp. 74-88). Oxford, UK: Oxford University Press.

McIntosh, M. J. (2005). Personality typology and thinking styles: Their role in framing and prospect theory. Advances in Consumer Research, 32(1), 253-255.

Narayan, A., Steele-Johnson, D., Delgado, K. M., \& Cole, P. A. (2007). Differential effects of pretraining influences on readiness to change. Journal of Psychology, 141(1), 47-60.

Nelson, D., \& Cooper, C. L. (2007). Positive organizational behavior: Accentuating the positive at work. Thousand Oaks, CA: Sage.

Noe, R. A. (1986). Trainees' attributes and attitudes: Neglected influences on training effectiveness. Academy of Management Review, 11(4), 736.

Orpen, C. (1999). The influence of the training environment on trainee motivation and perceived training quality. International Journal of Training and Development, 3(1), 34-43.

Parker, S. (1998). Enhancing role-breadth self-efficacy: The roles of job enrichment and other organizational interventions. Journal of Applied Psychology, 83, 835-852.

Petersen, C., \& Seligman, M. (2004). Character strengths and virtues. Oxford, UK: Oxford University Press.

Pfeffer, J. (1998). The human equation. Boston: Harvard Business School Press.

Quinones, M. A. (1995). Pretraining context effects: Training assignment as feedback. Journal of Applied Psychology, 80, 226-238.

Roberts, L. M. (2006). Shifting the lens on organizational life: The added value of positive scholarship. Academy of Management Review, 31, 292-305.

Ruth, J. \& York, A. (2004). Framing information to enhance corporate reputation: The impact of message source, information type, and reference point. Journal of Business Research, 57(1), 14-20.

Saks, A. M. (1995). Longitudinal field investigation of moderating and mediating effects of self-efficacy on the relationship between training and newcomer adjustment. Journal of Applied Psychology, 80, 211-225.

Salas, E., \& Cannon-Bowers, J. A. (2001). The science of training: A decade of progress. Annual Review of Psychology, 52, 471-499.

Salas, E., \& Kosarzycki, M. P. (2003). Why don't organizations pay attention to (and use) findings from the science of training? Human Resource Development Quarterly, 14(4), 487-491.

Scheier, M. F., \& Carver, C. S. (1985). Optimism, coping, and health: Assessment and implications of generalized outcome expectancies. Health Psychology, 4, 219-247.

Schwoerer, C. E., May, D. R., Hollensbe, E. C., \& Mend, J. (2005). General and specific selfefficacy in the context of a training intervention to enhance performance expectancy. Human Resource Development Quarterly, 16(1), 111-129.

Seligman, M. E. P. (1998). Learned optimism. New York: Pocket Books.

Seligman, M. E. P., \& Csikszentmihalyi, M. (2000). Positive psychology. American Psychologist, 55, 5-14.

Snyder, C. R. (1994). Hope and optimism. In V. S. Ramachandran, ed., Encyclopedia of human behavior (Vol. 2, pp. 535-542). San Diego, CA: Academic Press.

Snyder, C. R. (2000). Handbook of hope. San Diego, CA: Academic Press.

Snyder, C. R. (2002). Hope theory: Rainbows in the mind. Psychological Inquiry, 13, 249-275.

Snyder, C. R., \& Lopez, S. (2002). Handbook of positive psychology. Oxford, UK: Oxford University Press.

Snyder, C. R., Irving, L., \& Anderson, J. (1991). Hope and health: Measuring the will and the ways. In C. R. Snyder \& D. R. Forsyth, eds., Handbook of social and clinical psychology (pp. 285-305). Elmsford, NY: Pergamon. 
Snyder, C. R., Sympson, S., Ybasco, F., Borders, T., Babyak, M., \& Higgins, R. (1996). Development and validation of the state hope scale. Journal of Personality and Social Psychology, 70, 321-335.

Stajkovic, A. D., \& Luthans, F. (1998a). Self-efficacy and work-related performance: A meta-analysis. Psychological Bulletin, 24(2), 240-261.

Stajkovic, A. D., \& Luthans, F. (19980). Social cognitive theory and self-efficacy: Going beyond traditional motivational and behavioral approaches. Organizational Dynamics, 26(4), 62-74.

Tharenou, P., Saks, A., \& Moore, C. (2007). A review and critique of research on training and organizational level outcomes. Human Resource Management Review, 77(3), 251-273.

Tracey, J. B., Hinkin, T. R., Tannenbaum, S., \& Mathieu, J. E. (2001). The influence of individual characteristics and the work environment on varying levels of training outcomes. Human Resource Development Quarterly, 72, 5-23.

Training Magazine. (2006). 56 Billion budgeted for formal training: Training magazine's analysis of employer-sponsored training in the United States. Retrieved January 29, 2008, from Training Magazine 2006 Industry Report Web site: http://www.trainingmag.com/managesmarter/images/pdfs/IndRep06.pdf

Tugade, M. M., \& Fredrickson, B. L. (2004). Resilient individuals use positive emotions to bounce back from negative emotional experiences. Journal of Personality and Social Psychology, 86, 320-333.

Tugade, M. M., Fredrickson, B. L., \& Barrett, L. F. (2004). Psychological resilience and emotional granularity: Examining the benefits of positive emotions on coping and health. Journal of Personality, 72, 1161-1190.

Turner, N., Barling, J., \& Zacharatos, A. (2002). Positive psychology at work. In C. R. Snyder \& S. J. Lopez, eds., The handbook of positive psychology (pp. 715-728). New York: Oxford University Press.

Ulrich, D. (1997). Measuring human resources: An overview of practice and a prescription for results. Human Resource Management, 36(3), 303-320.

Valeda, R., Caetano, A., Michel, J. W., Lyons, B. D., \& Kavanagh, M. J. (2007). The effects of training design, individual characteristics and work environment on transfer of training. International Journal of Training and Development, 77(4), 282-294.

Wagnild, G. M., \& Young, H. M. (1993). Development and psychometric evaluation of the resiliency scale. Journal of Nursing Management, 1, 165-178.

Walumbwa, F. O., Avolio, B. J., Gardner, W. L., Wernsing, T. S., \& Peterson, S. J. (In press). Authentic leadership: Development and validation of a theory-based measure. Journal of Management.

Wiethoff, C. (2004). Motivation to learn and diversity training: Application of the theory of planned behavior. Human Resource Development Quarterly, 75(3), 263-248.

Wright, P. M., Dunford, B. B., \& Snell, S. A. (2001). Human resources and the resource based view of the firm. Journal of Management, 27(6), 701-721.

Wright, T. A. (2003). Positive organizational behavior: An idea whose time has truly come. Journal of Organizational Behavior, 24, 437-442.

Youssef, C. M., \& Luthans, F. (2007). Positive organizational behavior in the workplace: The impact of hope, optimism, and resilience. Journal of Management, 33(5), 774-800.

Zula, K. J., \& Chermack, T. J. (2007). Human capital planning: A review of literature and implications for human resource development. Human Resource Development Review, 6(3), 245-262. 